\title{
Effect of Land Use Changes of Upstream Komering Sub Watershed on Declining Water Availability
}

\author{
Agus Lestari Yuono', Dinar Dwi Anugerah Putranto1*, Sarino Tukirun'1 \\ 1 Department of Civil Engineering and Planning, Faculty of Engineering, Sriwijaya University, South Sumatera, \\ Indonesia \\ *Coresponding author's e-mail: dinar.dputranto@gmail.com
}

\begin{abstract}
Potential water resources in the upstream part of the Komering sub-watershed, in March each year ranges from $645.49 \mathrm{~m}^{3} / \mathrm{sec}$. With a debit of that size, it should be able to increase national agricultural production in South Sumatra, Indonesia. However, in August - September, the discharge of water availability in the upstream part of the Komering sub-watershed decreased to only $43.08 \mathrm{~m}^{3} / \mathrm{sec}$. To analyze the reduced mainstay discharge of the Upstream Komering sub-watershed, due to poor land use practices in the upstream area and the effects of climate variability, it can be analyzed by analyzing land cover conditions, the value of rain variability, and the magnitude of evapotranspiration and validation of direct measurement of river discharge in the field. Changes in land use for the upstream part of the Komering sub-watershed, which are used mostly by residents as community plantation areas, have increased the critical condition of the upstream Komering sub-watershed area of 2,517,560 $\mathrm{Km}^{2}$, or about $65.66 \%$ of the total upstream Komering sub-watershed. From the measurement of debit data at the Perjaya Dam in the last fifteen years (2005-2019), the largest main discharge value in 2 weeks to two months in April was $241.67 \mathrm{~m}^{3} / \mathrm{sec}$, while the smallest mainstay discharge occurred in the first 2 weeks of October at $54.69 \mathrm{~m} \mathrm{~m}^{3} / \mathrm{sec}$. A large difference between the largest and smallest mainstay discharge, it is necessary to think of a way so that the availability of water is always maintained throughout the year (the difference between the mainstay discharge between the rainy season and the dry season so that it is not so extreme). Some ways that can be done to maintain the availability of water include making a reservoir that can be used during the dry season, or increasing storage in the soil by reforestation and harvesting rain.
\end{abstract}

Keywords: discharge, land-use change, resources, harvesting

\section{INTRODUCTION}

The need for raw water from year to year will increase, along with the growth of world population (FAO, 2015). In Indonesia, the availability of water is expected to decrease further, along with population growth and ways of managing land that are still not suitable. Water resources in Indonesia are under increasing population pressure, rapid urbanization, industrial management and agricultural irrigation that does not pay attention to good management techniques, so that it is feared to lead to water scarcity and will threaten national food security. By 2025, around 1.8 billion people are expected to experience water scarcity, while two-thirds of the population will experience a lack of water availability (PBB,2014). Policy makers and stakeholders in the field of water resources management will face complex challenges due to a variety of situations including climate change ecosystems, water quality problems, increasing demand for clean water supply in urban areas and challenges to integrated, adaptive, and watershed management, collaborative. Areas with arid and semiarid climatic conditions will continue to be affected by water scarcity and soil moisture deficit problems. Farmers will face a major challenge because the distribution of spatial-temporal rainfall and unpredictable rainfall patterns cause climate uncertainty and the situation of changing seasons. These problems will affect agricultural production and will decrease 
food security. Sustainable management of water resources in the agricultural sector is very important to anticipate food crises and act as a catalyst for socio-economic development for the country. South Sumatera is one of the national food barns for Indonesia. Nearly $65 \%$ of the area in South Sumatera Province can become agricultural land. However, in recent years, due to inappropriate land management systems and a lot of land conversion to oil palm plantations, as well as deforestation that is not well controlled, the main discharge of some watershed areas has been disrupted. Many potential irrigation areas that have been designed to project water availability for decades to come, have experienced a very rapid decline in water quality and availability. One example, according to Yuono et all (2016), the Komering sub-watershed irrigation area, currently has experienced a substantial mainstay of depletion during the dry season (June-November), compared to the rainy season (November-June).

This study aims to analyze spatially, the condition of the mainstay of the discharge of the upper Komering sub-watershed, to determine the critical level of watershed in terms of its ability to be the main source of water supply for irrigation areas in South Sumatera, especially as the main source of water discharge at the Perjaya Dam in East OKU Regency, South Sumatera, in Indonesia.

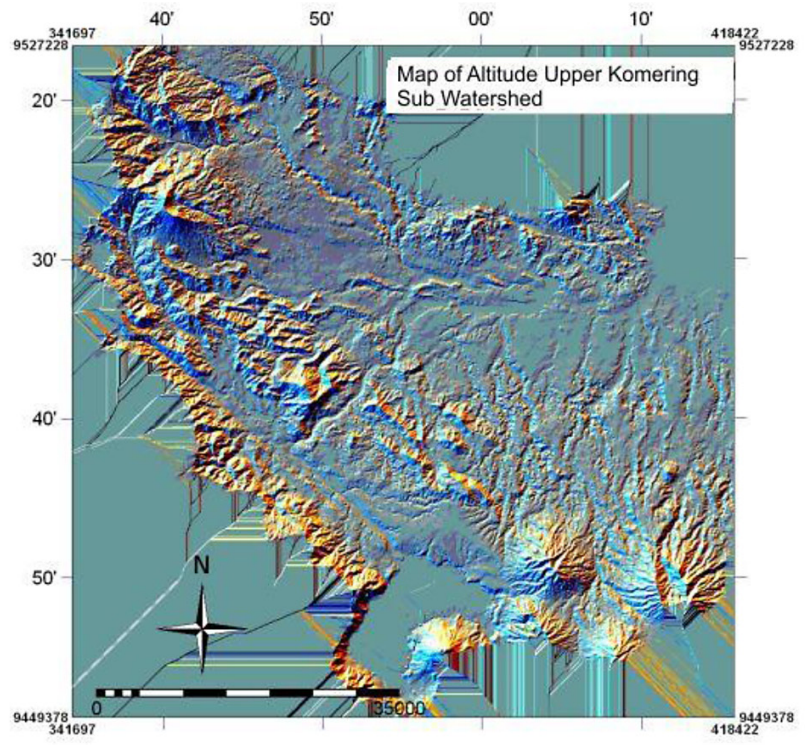

(a)

\section{MATERIAL AND METHODS}

The research area is located in the upstream part of Komering Sub Watershed, which is geographically located at coordinates $103^{\circ} 34^{\prime}$ $26^{\prime \prime}-104^{\circ} 19^{\prime} 15^{\prime \prime}$ East Longitude and between $4^{\circ} 16^{\prime} 22^{\prime \prime}-4^{\circ} 58^{\prime}$ '51" South Latitude (Figure 1). The area of the upstream sub-watershed Komering sub-area is $3,904 \mathrm{Km} 2$ which stretches from the upstream sub-watershed, namely Lake Ranau to the downstream part in Martapura village (Martapura District), East Ogan Komering Ulu (OKU), with the length of the main river of approximately $112 \mathrm{Km}$.

The average height of the upstream Komering sub-watershed, the highest area is $1,875 \mathrm{~m}$ above sea level and the lowest is at an altitude of $100 \mathrm{~m}$ above sea level.

Rainfall data was obtained from Banding Agung observation station (South OKU) at an altitude of $700 \mathrm{~m}$ above sea level and Belitang station (East OKU) with an altitude of $100 \mathrm{~m}$ above sea level for the period of observation for 12 years $(2006-2018)$. While the discharge measurements were obtained from measurements at the East OKU, Perjaya Dam, District of Martapura, from 2005 to June 2019. Climatology data collected were monthly data, consisting of temperature, solar radiation, relative humidity, and wind speed. As for the slope obtained from the DEM analysis using height data (contour) obtained from the Shuttle Radar Topography

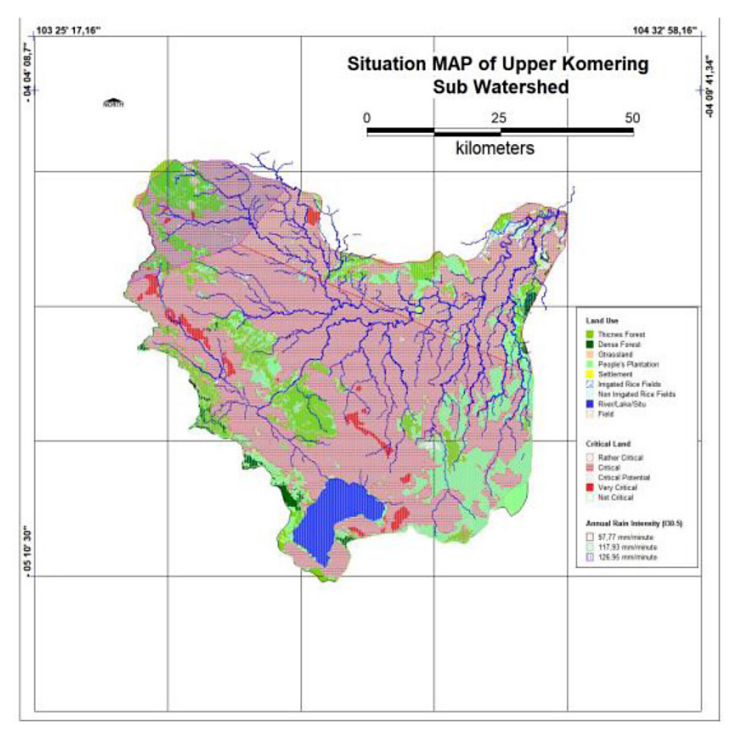

(b)

Figure 1. Komering sub catchment upstream areas, (a) altitude (b) land use, critical level and rainfall intensity 
Mission digital Elevation Model (SRTM) with a resolution of $25 \mathrm{~m}$, from the Balai Besar Wilayah Sungai (BBWS) region VIII, South Sumatera Province, in Indonesia (2016). Likewise, land use data, soil types and other data on a scale of 1: 50,000 were obtained from the BBWS region VIII, South Sumatera Province.

To calculate the mainstay debit data, used 10 years earlier to get the probability of success smaller or equal to 0.9 and 20 years to get the probability of success above 0.9 . For mainstay discharge irrigation purposes it is usually set at $80 \%(0.8)$, so that the minimum required data is 10 years or more.

Determination of mainstay discharge used Waibul equation (discharge duration curve), namely :

$$
P(X \geq \mathrm{x})=\frac{\mathrm{m}}{\mathrm{n}+1} 100 \%
$$

where: $P(\mathrm{X}>\mathrm{x})$ is the probability of the occurrence of variable $\mathrm{X}$ (discharge) equal to or greater than $\mathrm{x} \mathrm{m}^{3} / \mathrm{sec}$.

$m$ is data rank

$n$ is the amount of data

$X$ is a debit data series

$X$ is the mainstay debit data series if the probability matches the designation, for example $\mathrm{P}(\mathrm{X}>80 \%)=0.8$
The basic concept used to calculate water availability is the hydrological cycle developed by Mock (1978), in this case the focus of analysis is centered on discharge through the watershed system, including components of rain, evapotranspiration, interception, ground water, and water balance . Calculation of water balance is adification of the Thornthwaite method by ncluding limited evapotranspiration. It is also assumed that the green plants remain and the maximum soil moisture is $200 \mathrm{~mm}$. The $\mathrm{R}_{80}$ mainstay discharge is used for analysis of water availability.

\section{RESULTS}

Based on the results of monthly rainfall analysis for $\mathrm{R}_{80}$, the highest average rainfall was found in November - May, with maximum rainfall in December (195.15 mm/month), and the lowest rainfall occurred in August (13.19 mm/month).

From Figure 2 it can be seen, the magnitude of potential evapotranspiration is $128.73 \mathrm{~mm} /$ month in August and the lowest of $106.79 \mathrm{~mm} / \mathrm{month}$ for February. The total run-off for the upstream Komering watershed, with an average slope ranging from $8 \%-24 \%$, and mostly dominated by smallholder plantations with an average

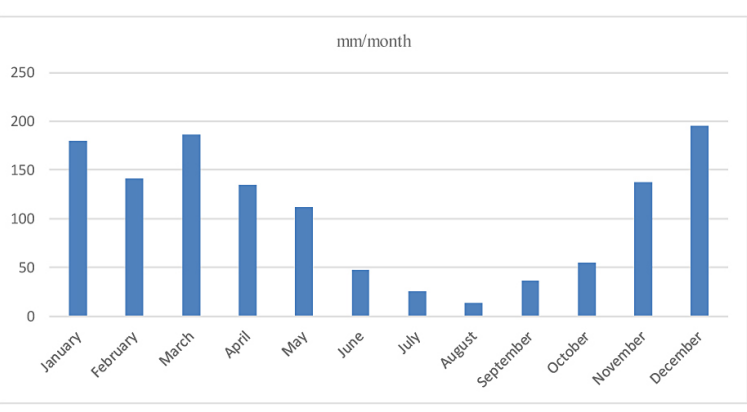

(a)

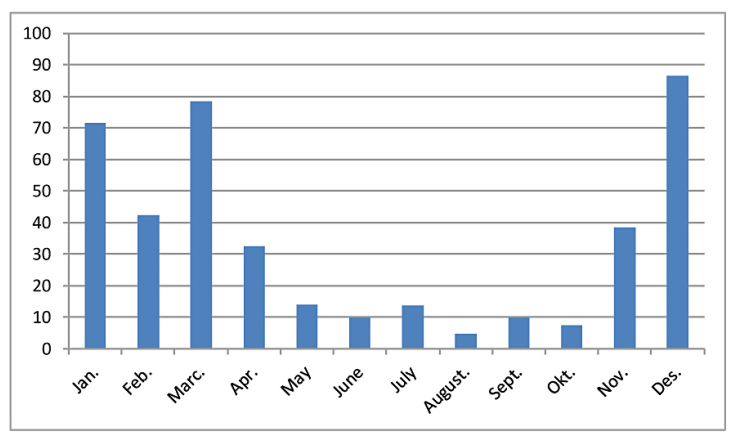

(c)

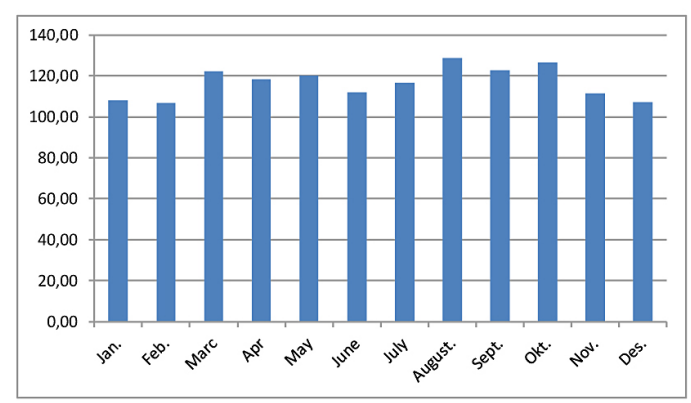

(b)

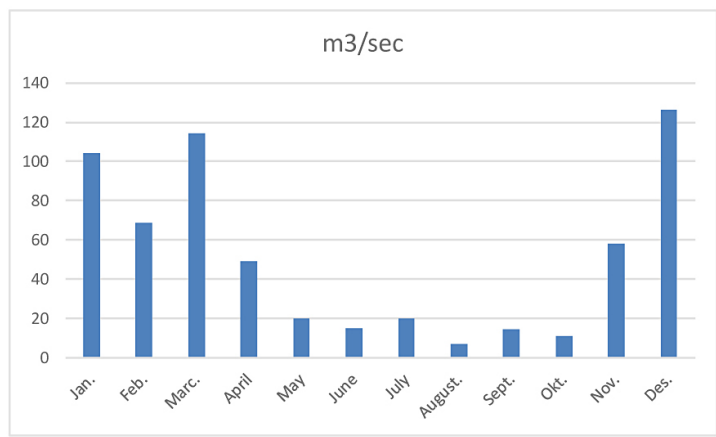

(d)

Figure 2 Calculation results for (a) Precipitation (mm / month); (b) potential evapotranspiration (monthly; $\mathrm{mm} / \mathrm{month}),(\mathrm{c})$ Total Run-off (mm / month); (d) Stream Flow $\left(\mathrm{m}^{3} / \mathrm{sec}\right)$ 
infiltration coefficient of 0.317 , the magnitude of the total run-off in the Komering sub-section The highest average upstream is between November to April, where the highest occurs in December $\left(86.61 \mathrm{~m}^{3} / \mathrm{sec}\right)$ and the lowest in August is $6.80 \mathrm{~m}^{3} / \mathrm{sec}$.Based on the above conditions, the largest amount of stream flow for the upstream Komering sub-watershed was $126.24 \mathrm{~m}^{3} / \mathrm{sec}$ in December and the lowest occurred in August at $6.80 \mathrm{~m}^{3} / \mathrm{sec}$. Based on the calculation of $\mathrm{R}_{80}$ using the Mock method, the highest value of the average main discharge occurs in November-May and the lowest in June-September, with the largest mainstay discharge in the second week of April at $248 \mathrm{~m}^{3} / \mathrm{sec}$ and the lowest in the month October of $52 \mathrm{~m}^{3} / \mathrm{sec}$.

Based on field measurements the observations and analysis of the water balance of the upstream Komering sub-watershed for the first planting period in October and November 2019 to 2024 were in October (a) devisit of $-32,668,480 \mathrm{~m}^{3}$ for 2019 , while in 2024 devisit will occur $-51,802,592 \mathrm{~m}^{3}$, and if the potential land to be developed has already been done by putting in a new paddy field, then the devisit of water will increase to twice, or equal to $-133,560,915 \mathrm{~m}^{3}$. While the volume of water shortages, during the first planting period in November 2024 (b), there was a devisit of water debit amounting to $-10,926,188.56 \mathrm{~m}^{3}$ in 2024 and will increase to a devisit - 37,352,510.45 $\mathrm{m}^{3}$ in the second planting period. And if the development of new fields is then carried out, the devisit of water will increase to $-51,127,851.69 \mathrm{~m}^{3}$.

\section{DISCUSSION}

The availability of water in a watershed is related to the arrival of water sources, namely the rainfall that enters the watershed, as well as the amount of evapotranspiration. The relationship between the availability of water (Debit) that can be accepted by the watershed with the extent of the watershed is very decisive, although the area is large but not necessarily the resulting discharge is also large. The relationship of water availability with Evapotranspiration is certainly influential because evapotranspiration will result in surface water and also water in plants will evaporate so that will result in reduced water that

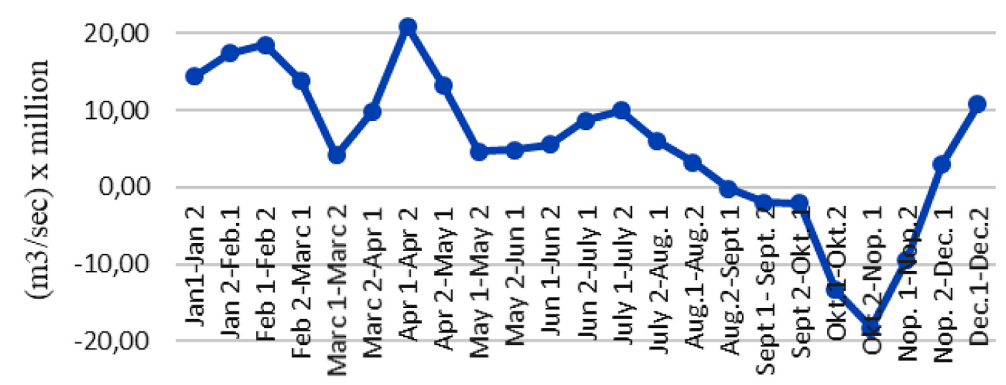

Figure 3. Water balance of the upstream Komering sub-watershed, observations and projections for Planting 1 (October until November to 2024)

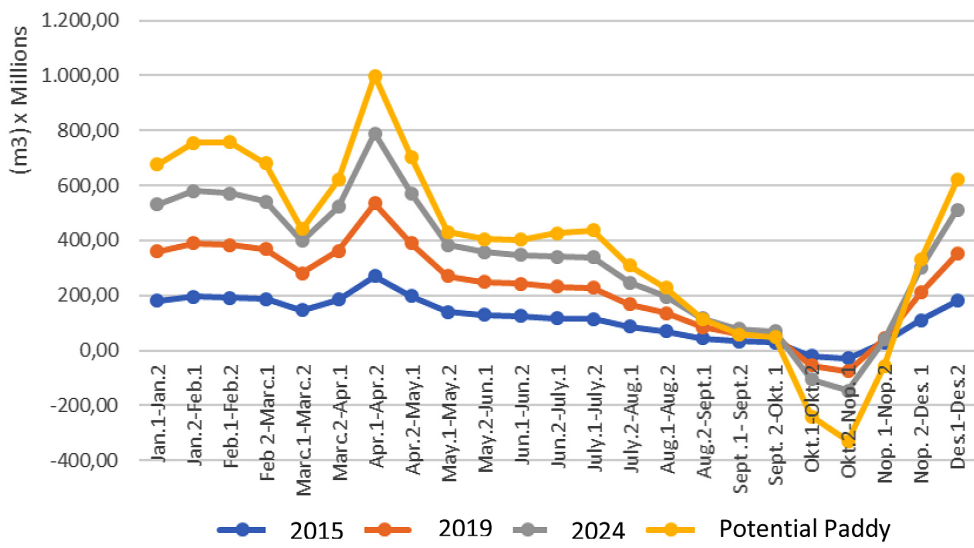

Figure 4. Mainstay discharge of the Komering river for one year is calculated every two weeks 
can be accepted by the watershed. Likewise, the relationship of water availability will be affected by the length of the river, if the river is long, it is certain that the volume of water it will load will also increase. With the length of the main rivers of the upstream Komering sub-watersheds along $112 \mathrm{Km}$, then the expected volume of upper Komering sub-watersheds should be able to flow through the Perjaya Dam irrigation area. But in fact the debit mainstay of the Perjaya dam is declining, due to inappropriate land management. This is closely related to land management in the upstream area, where if the rainy season and soil erosion occur, the river will be eroded so that siltation will occur which will result in reduced river capacity. If the capacity of the river decreases while the incoming water exceeds the capacity of the river, the river will overflow and sometimes cause flooding.

At the current upstream Komering Sub-watershed the maximum current is $269.80 \mathrm{~m}^{3} / \mathrm{sec}$ and a minimum discharge of $16.07 \mathrm{~m}^{3} / \mathrm{sec}$. Monthly average discharge of $116.59 \mathrm{~m}^{3} / \mathrm{sec}$. In April the upstream Komering Sub-watershed discharge was $125.28 \mathrm{~m}^{3} / \mathrm{sec}$. This is because the rainfall in the month is smaller because the sub-watershed only accepts rain only and does not receive runoff from other sub-watersheds. So that if it rains a little then the flow is also small or small. Long stream flow should be large because the river can hold more water, but the fact is that even though the river has a long amount of rain received in the watershed there is little or rarely rain, the flow will also be small. On this basis, efforts should be made to restrain the flow of runoff to enter more into the soil layer, which can be done by making more dams or reservoirs. At present, the construction of Tigadihaji Dam weir is still being carried out. If the three haze weir has been completed, then the amount of discharge capacity that can be utilized will still devisit water for irrigation of $299,699,256.72 \mathrm{~m}^{3}$.

\section{CONCLUSION}

Based on the results of the analysis and discussion above, it can be concluded as follows :

1. The recurrence of the mainstay discharge of the upstream Komering sub-watershed is due to an increase in the conversion of the land of the real estate plantations almost 34\% turned into various uses, so that it will reduce the function of water infiltration into the soil during the rainy season

2. To increase the main discharge of the Komering sub-watershed, it is necessary to make efforts to increase reservoirs and reservoirs of water (lakes) for efforts in harvesting rain for the continuity of agriculture in the area.

\section{Acknowledgements}

Thank you to the Research and Community Service Institute of Sriwijaya University for funding this research through the Competitive grant of the Sriwijaya University for the 2019/2020 fiscal year.

\section{REFERENCES}

1. Dinar Dwi Anugerah Putranto, Sarino, Yuono, AL, 2013, Model Monitoring Lingkungan DAS Untuk Pengendalian dan Mitigasi Bencana Banjir, FIT ISI Conference, no. 5, 213-2020

2. Kadyampakeni D.M., S. Kazombo-phiri, B. Mati, and I. R. Fandika, 2014, Impacts of Small-Scale Water Management Interventions on Crop Yield, Water Use and Productivity in Two Agro-Ecologies of Malawi," no. April, pp. 454-465.

3. FAO,2015, http://www.fao.org/ag/agp/ greenercities/en/whyuph/

4. Patil J.P., A. Sarangi P. SinghA. K. Singh.T. Ahmad, 2008, Development of a GIS Interface for Estimation of Runoff from Watersheds," Water Resour. Manag., vol. 22, no. 9, pp. 1221-1239.

5. Krois J, Schulte A (2014) GIS-based multi-criteria evaluation to identify potential sites for soil and water conservation techniques in the Ronquillo watershed, northern Peru. Appl Geogr 51:131-142

6. Ngigi, 2006. Hydrological Impacts of Land Use Changes on Water Resources managements and Social Economic Development of upper Ewaso Ng'iro River Basin in Kenya

7. Putranto Dinar DA, Yuono AL, Sarino, 2017. Spatial distribution level of land erosion dispotion based on the analysis of slope on central Lematang sub Basin. 3rd International Conference on Construction and Building Engineering (ICONBUILD) 2017. AIP, 1903, $0300071-0300078$.

8. United Nations (2014) Available online: http:// www.un.org/waterforlifedecade/scarcity.shtml

9. Yuono AL, Putranto Dinar DA, Sarino, 2015. Digital Terrain Model for Rainfall Run-off Modeling Regional Analysis of Sedimentation in the Musi River Basin, Sriwijaya University Research Institute, South Sumatera, Indonesia. 